\title{
製紙スラッジ-硫酸-高炉水砕スラグ-水酸化カルシウム系の 凝結硬化とアルミン酸ナトリウム添加の影響
}

青木繁 樹・木曽正光*.荒井康夫

$\left(\begin{array}{c}\text { 日本大学 理工学部 工業化学科 } \\ * \text { 富士不燃建材工業 }(\text { 株) }\end{array}\right.$

製紙スラッジ-硫酸-スラグ-水酸化カルシウム系の凝結, 硬化における水酸化カルシウムの作用 とアルミン酸ナトリウム添加の影響を検討し，次の結果を得た。

（1）製紙スラッジ-硫酸-スラグ系ではスラグ中の $\mathrm{CaO}$ 及び $\mathrm{MgO}$ 成分は塩基性物質として系 中の遊離硫酸と反応し, 硫酸カルシウム二水和物を生成し，その結果スラグ中の $\mathrm{SiO}_{2}$ 及び $\mathrm{Al}_{2} \mathrm{O}_{3}$ 成分の反応性が増大する.

( 2 ）この系に水酸化カルシウムを添加すると, $\mathrm{CaO}-\mathrm{Al}_{2} \mathrm{O}_{3}-\mathrm{CaSO}_{4} \cdot 2 \mathrm{H}_{2} \mathrm{O}$ 系からはエトリンガ イトが生成するが, 水酸化カルシウムの添加量が $\mathrm{CaO} / \mathrm{Al}_{2} \mathrm{O}_{3}$ モル比, $3 / 1$ 以下ではエトリンガイ 卜は非常に生成しにくい，それに反し，3/1 以上になるとこの系にはエトリンガイトが生成し，凝 結，硬化することが分った.

（３）この系の凝結はアルミン酸塩の添加により非常に促進された． $\mathrm{CaO} / \mathrm{CaSO}_{4} \cdot 2 \mathrm{H}_{2} \mathrm{O} / \mathrm{Al}_{2} \mathrm{O}_{3}$ モル比が 3/3/1 以上に $\mathrm{Ca}(\mathrm{OH})_{2}$ 及び $\mathrm{CaSO}_{4} \cdot 2 \mathrm{H}_{2} \mathrm{O}$ が存在するときは, $\mathrm{NaAlO}_{2}$ の添加により，工 トリンガイトが生成し, 凝結が早くなり, 強度も増大したが, $\mathrm{Ca}(\mathrm{OH})_{2}$ 及び $\mathrm{CaSO}_{4} \cdot 2 \mathrm{H}_{2} \mathrm{O}$ のゼち らか欠けるときは，エトリンガイトの生成がなく，凝結は早くなるが，強度は低下した。

(1984 年 1 月 27 日受付)

\section{Setting and Hardening of the System of Paper Sludge-Sulfuric Acid-Slag-Calcium Hydroxide and the Effect of Sodium Aluminate as Additive}

\author{
Shigeki AOKI, Masamitsu KISO* and Yasuo ARAI \\ Department of Industrial Chemistry, Faculty of Science and Engineering, Nihon University \\ 1-8, Kanda Surugadai, Chiyoda-ku, Tokyo 101 \\ * Fuji Fire-Proof Material Industry Co., Ltd.
}

The effect of calcium hydroxide and aluminate on the setting and hardening of the system of paper sludge-sulfuric acid-slag-calcium hydroxide was investigated. The results obtained were as follows.

(1) In the system of paper sludge-sulfuric acid-slag, the $\mathrm{CaO}$ and $\mathrm{MgO}$ components in the slag reacted with free sulfuric acid. This reaction caused the formation of calcium sulfate dihydrate and the increase of the reactivity of $\mathrm{SiO}_{2}$ and $\mathrm{Al}_{2} \mathrm{O}_{3}$ components in the reacted slag.

(2) The addition of calcium hydroxide into this system resulted in the formation of ettringite. When the amount of calcium hydroxide added was less than 3 in the molar ratio of $\mathrm{CaO} / \mathrm{Al}_{2} \mathrm{O}_{3}$, it was difficult to form ettringite. On the other hand, when the molar ratio was more than 3 , the formation of ettringite was observed in the system, and the paste of the system set and hardened.

( 3 ) Setting of the paste of the system was accelerated markedly with the addition of aluminate. When $\mathrm{Ca}(\mathrm{OH})_{2}$ and $\mathrm{CaSO}_{4} \cdot 2 \mathrm{H}_{2} \mathrm{O}$ were present more than $3 / 3 / 1$ in the molar ratio of $\mathrm{CaO} / \mathrm{CaSO}_{4} \cdot 2 \mathrm{H}_{2} \mathrm{O} / \mathrm{Al}_{2} \mathrm{O}_{3}$, the addition of $\mathrm{NaAlO}_{2}$ caused the formation of ettringite and the increase of the strength of hardened bodies. When there was no $\mathrm{Ca}(\mathrm{OH})_{2}$ or $\mathrm{CaSO}_{4} \cdot 2 \mathrm{H}_{2} \mathrm{O}$, ettringite did not form and the strength of the hardened bodies decreased by the addition of 
$\mathrm{NaAlO}_{2}$.

Key-words: Paper sludge, Granulated blast furnace slag, Sulfuric acid, Aluminate, Setting and hardening

\section{1. 緒言}

製紙工業では木材パルプにタルク，クレーなどの無機 質充てん剂を加え，大量の水で処理し紙を製造している が，その一部は排水中に流出する，そこで，その排水に 凝集沈殿剂を加え, 排水中の流出した懸濁物質を沈殿さ せ，除去してから放流している，この沈殿が製紙スラッ ジであるが，大量に発生するので，その処分及び有効利 用が大きな社会問題となっている”。

著者らは古紙を再生する際の製造排水より生ずる製紙 スラッジの有効利用を考え，この製紙スラッジを大量に 混入した硬化体の作製を検討し，製紙スラッジを硫酸処 理した後, 石灰を加え, 炭酸化した製紙スラッジ混入石 灰硬化体の試製 2 と, 製紙スラッジの硫酸処理後, これ に高炉水砕スラグ（以下スラグと呼ぶ）を添加し，製紙 スラッジー硫酸ースラグー水酸化カルシウム系で比較的良 好な硬化体が作製できることを報告した 告は，いずれも製紙スラッジをまず硫酸溶液で処理して いるが, 硫酸処理の利点としては, この処理により製紙 スラッジの乾燥収縮が大幅に減少し, 製紙スラッジを大 量に混入した硬化体の作製が可能になるきことである.

しかし, 硫酸処理すると, 中和後にポルトランドセメン 卜系のセメント類を添加しても硬化しないという久点も でてくる．しかし，硫酸処理後に中和することなくスラ グを加え，スラッジ中の遊離硫酸亡スラグを反応させる 上, 水酸化カルシウムの添加により硬化するようになる. そこで，この方法で製紙スラッジ-硫酸-スラグ-水酸化 カルシウム系の硬化体を作製したが, まだ凝結時間が長 いという欠点をもっている.この欠点を取り除くため, 凝結に及ぼす各種塩類の影響を検討したが, 凝結促進に はアルミン酸塩が特に有効であることが分り, また, 凝 結, 硬化に及ぼす水酸化カルシウム及びアルミン酸塩の 作用を検討することにより, この系の凝結, 硬化の機構 も明確になったのでこれらについて報告する。なお，本 報告では良好な硬化体の得られる製紙スラッジ，15\% 硫酸溶液, スラグの配合比 $200 \mathrm{~g} / 200 \mathrm{ml} / 100 \mathrm{~g}$ のもの ${ }^{31}$ に水酸化カルシウム及びアルミン酸塩を添加した例につ
いてのみ報告する．

\section{2. 実験方法}

\section{1 製紙スラッジ及びスラグ}

各種の製紙スラッジの組成を表 1 に，実験に使用した 製紙スラッジのX X 線回折図を図 1 に示した。実験に使 用した製紙スラッジは古紙系のもので，固形分中の Ig. loss，すなわち植物纎維が 50 \% 以下で，粘土分が $60 \%$ 近くあり，自燃性がなく重油を混合して焼却し，焼却灰 として廃棄しているものである。なお, 図 1 の X 線回 折図には $2 \theta(\mathrm{Cu}, K \alpha) 9.4^{\circ}, 12.3^{\circ}, 22.4^{\circ}, 24.6^{\circ}$, 28. $3^{\circ}$ にはピークが認められる。帰属が不明確であるが これらのピークは粘土系鉱物によるものと考えられる. この古紙系の製紙スラッジは固形分 $35 \sim 40 \%$ ，水分 65 ～60\% からなるが，入手ごとに水分量にかなりの変動 があったので，入手ごとに水分量の測定をし，純水を加 え，固形分 $30 \%$, 水分 $70 \%$ に調整して用いた.

使用したスラグの化学組成を表 2 に示した.

実験にはこのほかにアルミン酸ナトリウム，水酸化カ ルシウム，硫酸等を使用したが，いずれも試薬 1 級以上 を用いた。なお，アルミン酸ナトリウムは試薬ラベルに

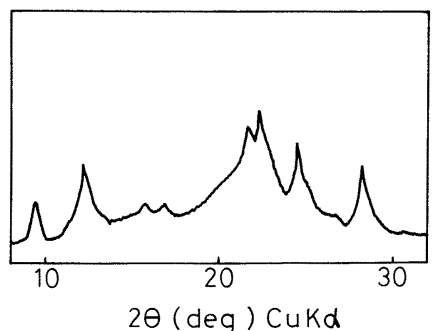

Fig. 1. X-ray diffraction pattern of paper sludge.

Table 2. Chemical composition of granulated blast furnace slag $(\%)$.

$\begin{array}{llllllllll}\mathrm{CaO} & \mathrm{MgO} & \mathrm{SiO}_{2} & \mathrm{Al}_{2} \mathrm{O}_{3} & \mathrm{Fe}_{2} \mathrm{O}_{3} & \mathrm{MnO} & \mathrm{SO}_{3} & \begin{array}{l}\text { Ig. } \\ \text { loss }\end{array} & \begin{array}{l}\text { In. } \\ \text { sol. Total }\end{array}\end{array}$ $\begin{array}{llllllllll}41.2 & 6.4 & 35.0 & 15.2 & 0.9 & 0.9 & 0.9 & -0.1 & 0.1 & 100.3\end{array}$

Table 1. Chemical composition of various paper sludge (\%).

\begin{tabular}{lcc|c|c|c|c|c|c|c}
\hline & \multirow{2}{*}{$\begin{array}{c}\text { Solid } \\
\text { Material } \\
(\%)\end{array}$} & $\begin{array}{c}\text { Water } \\
\text { content } \\
(\%)\end{array}$ & \multicolumn{6}{c}{ Chmical composition in solid material } \\
\cline { 5 - 11 } & & & Ig. loss & $\mathrm{SiO}_{2}$ & $\mathrm{Al}_{2} \mathrm{O}_{3}$ & $\mathrm{Fe}_{2} \mathrm{O}_{3}$ & $\mathrm{CaO}$ & $\mathrm{MgO}$ & $\mathrm{Total}$ \\
\hline Kraft paper & \multirow{2}{*}{$20-30$} & $80-70$ & 76.0 & 6.0 & 13.0 & 0.5 & 2.6 & 0.1 & 98.2 \\
Machine paper
\end{tabular}


$\mathrm{NaAlO}_{2}$ と表示してあり， $\mathrm{Al}_{2} \mathrm{O}_{3}$ として $35 \pm 5 \%$ を保証 してあったので, $\mathrm{Al}_{2} \mathrm{O}_{3}$ 成分の含有量を $35 \%$ として反 応量の計算を行った.

\section{2 硬化体の作製方法及び強さ試験}

まず，含水量を $70 \%$ に調整した製紙スラッジ $200 \mathrm{~g}$ に $15 \%$ 硫酸溶液 (conc. $\mathrm{H}_{2} \mathrm{SO}_{4}$ の容量 \%) $200 \mathrm{ml}$ を 加え, $85 \pm 1^{\circ} \mathrm{C}$ に加熱し, 1 時間の硫酸処理を行った. このスラッジスリラーは酸性で, ガラス電極による $\mathrm{pH}$ の測定值はマイナス側にスケールアウトし，目側による 測定值はー0.10〜ー0.12であった.

この硫酸処理製紙スラッジスラリーにスラグ $100 \mathrm{~g} を$ 加え，室温でスラグとスラリーを 3 時間反応させた。 ス ラグは硫酸溶液中では塩基性物質として挙動する ${ }^{4)}$ の で，スラリー液相の $\mathrm{pH}$ はスラグの添加により，4.0 前 後まで上昇する.このスラリーに水酸化カルシウムを添 加して中和 (約 $0.6 \mathrm{~g}$ 必要) しただけでは硬化しないが, 更に過剩の水酸化カルシウムを添加し, 混練すると硬化 する. 中和後, 各種添加量の水酸化カルシウムを添加し, 5 分間混練し, $2 \times 2 \times 8 \mathrm{~cm}$ の型枠に流し込み, 成形し, 24 時間後に脱型した。得られた成形体を室温で，24 時

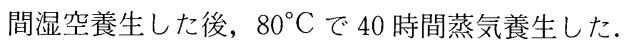

養生が終了した硬化体は $40^{\circ} \sim 45^{\circ} \mathrm{C}$ の熱風乾燥機で 24 時間乾燥した後, かさ比重を測定し, その後曲げ強 さ及び圧縮強さを測定した。

\section{3 凝結試験}

凝結試験はセメントの JIS 規格に準じてビカ一針装 置を用いて行ったが，凝結針は $1 \mathrm{~mm}$ 針ではなく，1 $\mathrm{mm}$ 針と同重量の自家製の $4 \mathrm{~mm}$ 針を使用した. JIS 規 格では凝結試験にセメントペーストを使用しているが， 本報告では硬化体作製と同じ配合の製紙スラッジを含ん だペーストの凝結を測定した。この場合, ペーストの硬 化性がおとり，1 $\mathrm{mm}$ 針では凝結がはっきりしなかった ので，便宜的に $4 \mathrm{~mm}$ 針にかえて測定した。なお，凝結 試験では水酸化カルシウム添加後, 適量の純水を加え, 軟度をセメント規格の軟度棒を用い, 底面より $20 \pm 1$ $\mathrm{mm}$ に止まるような軟度にして測定した。

\section{4 凝結硬化中の固相の $\mathrm{X}$ 線回折}

混練したペーストを所定時間ごとに適量分取し，エ夕 ノール中に分散させ水和を止め，エチルエーテルで洗浄 後, 24 時間以上真空デシケーター中で乾燥して X 線回 折を行った。

\section{3. 実験結果及び考察}

3.1 製紙スラッジ-硫酸-スラグ-水酸化カルシウム系 の凝結, 硬化

製紙スラッジ（含水率 $70 \%$ ） $200 \mathrm{~g}$ を $15 \%$ 硫酸溶液 $200 \mathrm{ml}$ で硫酸処理した後, これに高炉水砕スラグ $100 \mathrm{~g}$ を添加し, 硫酸処理製紙スラッジ中の遊離硫酸とスラグ
を反応させたもの（以後 $200 \mathrm{~g} / 200 \mathrm{ml} / 100 \mathrm{~g}$ 配合物と略 称する）に，種々の添加量の水酸化カルシウムを添加し たときの凝結曲線及び硬化体の圧縮強さを図 2 , 図 3 に 示した.

図 2 によると, 水酸化カルシウムの添加量が $20 \mathrm{~g}$ で は凝結は非常に遅く，混練後 4〜5 時間頃より凝結針の 浸入度は低下し始めるが，7 時間でも底面より $6 \mathrm{~mm}$ (上 面より $34 \mathrm{~mm}$ ) まで漫入しており，22 時間後でも凝結 針の浸入度は上面より $5 \mathrm{~mm}$ もあり, 硬化性が不良で, 翌日脱型が不可能である.これに対し, 水酸化カルシウ ムの添加量が $25 \mathrm{~g}$ 以上では混練後 1 2 時間頃より凝結 が始まり, 添加量の増加に従って凝結は早くなり, 凝結 曲線は左側に移動する。しかし, 水酸化力ルシウムの添 加だけでは凝結促進に限界があり，40 g 以上添加して も凝結はこれ以上あまり速くならない。

硬化体の強度に及ぼす水酸化カルシウムの影響は図 3 に示してあるが, 凝結に及ぼす影響とほぼ同様で, 凝結 が遅い $30 \mathrm{~g}$ 以下の添加量では強度は非常に小さいが, $35 \mathrm{~g}$ 以上の添加では強度は急激に増大し，50〜 55 g の 添加で最高の強度が得られる.

水酸化カルシウムの添加量により, 凝結及び硬化性は 非常に異なるが，この系の凝結硬化中の固相の変化を知 るため, 硬化性の良好な水酸化カルシウムの添加量が

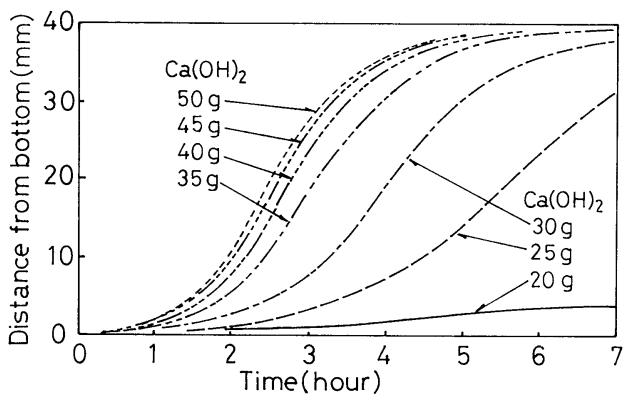

Fig. 2. Effect of $\mathrm{Ca}(\mathrm{OH})_{2}$ on setting curves in paper sludge $200 \mathrm{~g}-15 \% \mathrm{H}_{2} \mathrm{SO}_{4} 200 \mathrm{ml}$-slag $100 \mathrm{~g}-\mathrm{Ca}(\mathrm{OH})_{2}$.

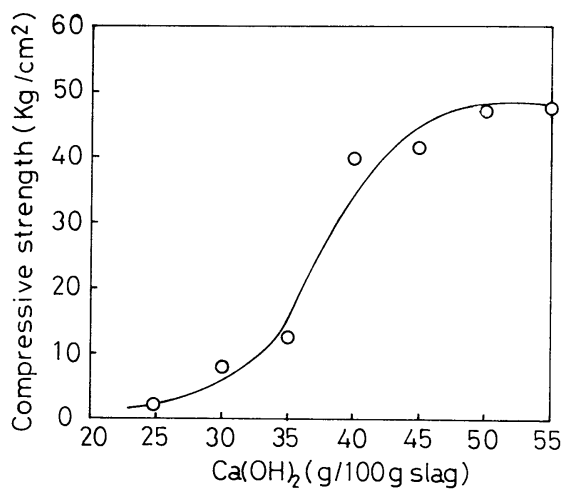

Fig. 3. Effect of $\mathrm{Ca}(\mathrm{OH})_{2}$ on compressive strength of hardened bodies in paper sludge $200 \mathrm{~g}-15 \% \mathrm{H}_{2} \mathrm{SO}_{4}$ $200 \mathrm{ml}$-slag $100 \mathrm{~g}-\mathrm{Ca}(\mathrm{OH})_{2}$. 


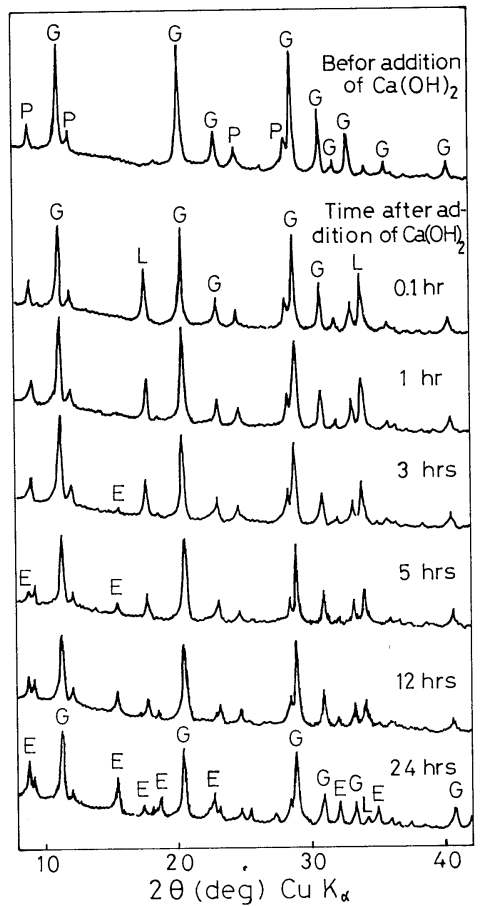

Fig. 4. $\dot{X}$-ray diffraction patterns of solid phases during setting in paper sludge $200 \mathrm{~g}-1.5 \% \mathrm{H}_{2} \mathrm{SO}_{4}$ $200 \mathrm{ml}$-slag $100 \mathrm{~g}-\mathrm{Ca}(\mathrm{OH})_{2} 50 \mathrm{~g} \mathrm{P}$ : Paper sludge, $\mathrm{G}: \mathrm{CaSO}_{4} \cdot 2 \mathrm{H}_{2} \mathrm{O}, \mathrm{E}:$ Ettringite, $\mathrm{L}: \mathrm{Ca}(\mathrm{OH})_{2}$.

$50 \mathrm{~g}$ の配合物の凝結硬化中の固相の X 線回折を行った. 水酸化力ルシウム添加前及び添加後の固相の X 線回折 図の経時変化を図 4 に示した.

図 4 はピークの数が多く複雑にみえるが, 製紙スラッ ジに起因するピーク P (製紙スラッジ中の粘土類の回 折ピーク) を除くと比較的簡単になる. 硫酸処理製紙ス ラッジにスラグを添加したもの，すな わち水酸化カルシウム添加前の固相の $\mathrm{X}$ 線回折図には $\mathrm{P}$ 以外に硫酸カルシ ウム二水和物のピーク Gだけしか認 められない。これに水酸化カルシウム $50 \mathrm{~g}$ を添加し, 混練すると, $2 \theta$, $18.1^{\circ}$ と $34.1^{\circ}$ にかなり大きな水酸化 カルシウムの回折ピーク L が生ずる. しかし，時間の経過に従って，この $\mathrm{L}$ 及び $\mathrm{G}$ のピークは小さくなり，3 時間頃からエトリンガイトEの回折 ピークが出現し, 時間の経過に従って このピークは大きくなっている。した がって, この系の凝結, 硬化にはエト リンガイトの生成が関与していること は明らかであり，硫酸処理製紙スラッ ジにスラグを添加したときには，まず スラッジ中の遊離硫酸とスラグが反応

$(0.123 \mathrm{~mol})$
し，硫酸カルシウム二水和物が生成する。これに水酸化 カルシウムを添加するとスラグ中の $\mathrm{Al}_{2} \mathrm{O}_{3}$ 成分も反応に 加わり, $\mathrm{CaO}-\mathrm{Al}_{2} \mathrm{O}_{3}-\mathrm{CaSO}_{4}-\mathrm{H}_{2} \mathrm{O}$ 系より，徐々にエト リンガイトが生成し，凝結，硬化したものと考えられる.

\section{2 エトリンガイトの生成反応}

この系の凝結，硬化にはエトリンガイトの生成がもつ とも重要な働きをしていると考えられる，そこで，製紙 スラッジ-硫酸-スラグ-水酸化カルシウム系よりエトリ ンガイトが生成する反応について, 分析值を利用し，二， 三の仮定をし，計算により，その生成量を算出した。

まず,製紙スラッジは硫酸処理しても硫酸と反応せず, 加えた硫酸は遊離硫酸として，全量がスラグと反応する と仮定した。ただし，製紙スラッジ $200 \mathrm{~g}$ を $15 \%$ 硫酸 溶液 $200 \mathrm{ml}$ で処理したときに, 製紙スラッジより液相 に $\mathrm{Al}_{2} \mathrm{O}_{3}$ として $3.43 \mathrm{~g}(0.0336 \mathrm{~mol})$ が溶出したので, この $\mathrm{Al}_{2} \mathrm{O}_{3}$ は反応の計算にとり入れた.

反応の当量関係を整理したものを表 3 に示した.

表 2 のスラグの化学組成より, スラグ $100 \mathrm{~g}$ 中には,

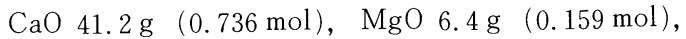
$\mathrm{Al}_{2} \mathrm{O}_{3} 15.2 \mathrm{~g} \quad(0.149 \mathrm{~mol}), \mathrm{SiO}_{2} 35.0 \mathrm{~g} \quad(0.582 \mathrm{~mol})$ 含まれる. 括弧内はモル数で示したもので, 表 3 では成 分含有量を主にモル数で示してある. 硫酸処理製紙ス ラッジにスラグを添加した場合には硫酸と製紙スラッジ が反応しないと仮定しているので, 反応量の関係はスラ グ $100 \mathrm{~g}$ に $15 \%$ 硫酸溶液 $200 \mathrm{ml}\left(\mathrm{H}_{2} \mathrm{SO}_{4}\right.$ として 0.535 $\mathrm{mol}$ ) を反応させたことになる．スラグと酸溶液との反 応ではスラグは塩基性物質として作用し，スラグ中の $\mathrm{CaO}$ 成分及び $\mathrm{MgO}$ 成分は酸と優先的に反応する ${ }^{4)}$. そ こで，スラグ中の換算 $\mathrm{CaO}$ は $(1)$ 式に従って反応す る.なお，ここで, $(\mathrm{CaO}+\mathrm{MgO})$ のモル数を換算

Table 3. Reaction mechanism of paper sludge $-\mathrm{H}_{2} \mathrm{SO}_{4}^{-}$ slag- $\mathrm{Ca}(\mathrm{OH})_{2}-\mathrm{Al}_{2} \mathrm{O}_{3}$ system.

Slag $100 \mathrm{~g}\left(\mathrm{CaO}-\mathrm{MgO}-\mathrm{Al}_{2} \mathrm{O}_{3}-\mathrm{SiO}_{2}\right)+\mathrm{Al}_{2} \mathrm{O}_{3}$ from Paper sludge $(0.736 \mathrm{~mol})(0.159 \mathrm{~mol})(0.149 \mathrm{~mol})(0.582 \mathrm{~mol}) \quad(0.0336 \mathrm{~mol})$

+15 vol. $\% \mathrm{H}_{2} \mathrm{SO}_{4} 200 \mathrm{ml}\left(\mathrm{H}_{2} \mathrm{SO}_{4}: 0.535 \mathrm{~mol}\right)$

Degree of reaction ; $0.598(0.535 /(0.736+0.159))$

$\mathrm{CaSO}_{4} \cdot 2 \mathrm{H}_{2} \mathrm{O}+\mathrm{MgSO}_{4}+\mathrm{Al}_{2} \mathrm{O}_{3}-\mathrm{SiO}_{2}-\mathrm{H}_{2} \mathrm{O}+\mathrm{Slag}$

$(0.440 \mathrm{~mol}) \quad(0.095 \mathrm{~mol})(0.123 \mathrm{~mol})(0.348 \mathrm{~mol}) \quad(40.2 \mathrm{~g})$

$\downarrow+\mathrm{Ca}(\mathrm{OH})_{2} 7.0 \mathrm{~g}(0.095 \mathrm{~mol})$

$\mathrm{CaSO}_{4} \cdot 2 \mathrm{H}_{2} \mathrm{O}+\mathrm{Mg}(\mathrm{OH})_{2}+\mathrm{Al}_{2} \mathrm{O}_{3}-\mathrm{SiO}_{2}-\mathrm{H}_{2} \mathrm{O}+$ Slag

$(0.535 \mathrm{~mol})(0.095 \mathrm{~mol})(0.123 \mathrm{~mol})(0.348 \mathrm{~mol}) \quad(40.2 \mathrm{~g})$

$\downarrow+1-\mathrm{Ca}(\mathrm{OH})_{2} 27.3 \mathrm{ig}\left(0.123 \times 3=0.369 \mathrm{~mol} \quad \mathrm{Ca}(\mathrm{OH})_{2}\right)$

$3 \mathrm{CaO} \cdot \mathrm{Al}_{2} \mathrm{O}_{3} \cdot 3 \mathrm{CaSO}_{4} \cdot 31 \mathrm{H}_{2} \mathrm{O}+\mathrm{H}^{-} \mathrm{CaSO}_{4} 2 \mathrm{H}_{2} \mathrm{O}+\mathrm{SiO}_{2} \mathrm{H}-\mathrm{Mg}(\mathrm{OH})_{2}+\mathrm{Slag}$ (0.186 mol)

(40.2g) 
$\mathrm{CaO}$ と呼ぶことにした（換算 $\mathrm{CaSO}_{4} \cdot 2 \mathrm{H}_{2} \mathrm{O}$ も同様）

$\mathrm{H}_{2} \mathrm{SO}_{4}+\mathrm{CaO} \stackrel{\mathrm{H}_{2} \mathrm{O}}{\rightarrow} \mathrm{CaSO}_{4} \cdot 2 \mathrm{H}_{2} \mathrm{O}$

反応当量 $1 \mathrm{~mol} \quad 1 \mathrm{~mol} \quad 1 \mathrm{~mol}$

反応前 $0.535 \mathrm{~mol} \quad 0.895 \mathrm{~mol} \quad 0 \mathrm{~mol}$

反志後 $0 \mathrm{~mol} \quad 0.360 \mathrm{~mol} \quad 0.535 \mathrm{~mol}$

反応量の計算を( 1 )式の下に示したが，スラグ $100 \mathrm{~g}$ 中に含まれる換算 $\mathrm{CaO} 0.895 \mathrm{~mol}$ 中の $0.535 \mathrm{~mol}$ が硫 酸と反応し，換算 $\mathrm{CaSO}_{4} \cdot 2 \mathrm{H}_{2} \mathrm{O}$ が $0.535 \mathrm{~mol}$ 生成する ことになる.したがって換算 $\mathrm{CaO}$ の反応率は 0.598 と なる. スラグの反応率は換算 $\mathrm{CaO}$ の反応率と等しいと 仮定すれば，スラグの反応率は 0.598 となる。したがっ て反応後には未反応スラグが $40.2 \mathrm{~g}$ 含まれ, $\mathrm{CaSO}_{4}$ $2 \mathrm{H}_{2} \mathrm{O}$ が $0.440 \mathrm{~mol}, \mathrm{MgSO}_{4}$ が $0.095 \mathrm{~mol}$ 生成する. このほかに反応したスラグも含まれる（この固相には $\mathrm{SiO}_{2}$ 成分は $0.348 \mathrm{~mol}, \mathrm{Al}_{2} \mathrm{O}_{3}$ 成分は $0.089 \mathrm{~mol}$ 含まれ る).この状態の $\mathrm{X}$ 線回折図が，図 4 の $\mathrm{Ca}(\mathrm{OH})_{2}$ 添加 前の回折図であるが，この図には製紙スラッジに起因す る回折ピーク P 以外に硫酸カルシウム二水和物のピー ク $G$ だけしか認められない。したがって，硫酸処理ス ラッジにスラグを添加した場合には（1）式の反応が起 こり, 硫酸カルシウム二水和物が生成するが, 二水和物

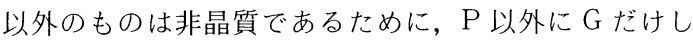
か認められなかったものと考えられる。なお，硫酸溶液 とスラグの反応後には $\mathrm{MgSO}_{4}$ が $0.095 \mathrm{~mol}$ 生成してい るが, 水酸化カルシウムを $0.095 \mathrm{~mol}(7.0 \mathrm{~g})$ 添加すれ ば，（2）式の反応が起こり

$$
\mathrm{MgSO}_{4}+\mathrm{Ca}(\mathrm{OH})_{2} \stackrel{\mathrm{H}_{2} \mathrm{O}}{\rightarrow} \mathrm{CaSO}_{4} \cdot 2 \mathrm{H}_{2} \mathrm{O}+\mathrm{Mg}(\mathrm{OH})_{2}
$$

$\mathrm{CaSO}_{4} \cdot 2 \mathrm{H}_{2} \mathrm{O}$ と $\mathrm{Mg}(\mathrm{OH})_{2}$ がそれぞれ $0.095 \mathrm{~mol}$ 生成 する. $\mathrm{CaSO}_{4} \cdot 2 \mathrm{H}_{2} \mathrm{O}$ は合計 $0.535 \mathrm{~mol}$ 生成することに なる.

反応したスラグの形態は分らないが，反応した固相中 の $\mathrm{SiO}_{2}$ 成分及び $\mathrm{Al}_{2} \mathrm{O}_{3}$ 成分は反応しやすい状態になっ ていると考えられる.これに水酸化カルシウムを添加す ると固相中のこの $\mathrm{Al}_{2} \mathrm{O}_{3}$ 成分 $(0.089 \mathrm{~mol})$ と製紙スラッ ジより溶出した $\mathrm{Al}_{2} \mathrm{O}_{3}(0.0336 \mathrm{~mol})$ と生成した硫酸力 ルシウム二水和物より（3）式によりエトリンガイトを 生成する $\left(\mathrm{SiO}_{2}\right.$ 成分の反応は 3.3 節で論じる).

$$
\begin{gathered}
3 \mathrm{Ca}(\mathrm{OH})_{2}+\mathrm{Al}_{2} \mathrm{O}_{3}+3 \mathrm{CaSO}_{4} \cdot 2 \mathrm{H}_{2} \mathrm{O} \stackrel{\mathrm{H}_{2} \mathrm{O}}{\rightarrow} \\
3 \mathrm{CaO} \cdot \mathrm{Al}_{2} \mathrm{O}_{3} \cdot 3 \mathrm{CaSO}_{4} \cdot 31 \mathrm{H}_{2} \mathrm{O}
\end{gathered}
$$

反応当量 $3 \mathrm{~mol} 1 \mathrm{~mol} \quad 3 \mathrm{~mol} \quad 1 \mathrm{~mol}$

反応前 $x$ mol $0.123 \mathrm{~mol} \quad 0.535 \mathrm{~mol} \quad 0 \mathrm{~mol}$

反応後 $0 \mathrm{~mol}(0.123-\quad(0.535-x / 3 \mathrm{~mol}$

$$
x / 3) \mathrm{mol} \quad x) \mathrm{mol}
$$

(3) 式の下に水酸化カルシウムを $x \mathrm{~mol}$ 添加したと きの反応量も示した. $x$ が大きくなればエトリンガイト の生成量 $x / 3$ は増加するが, $(0.123-x / 3) \geqq 0$ $(x \leqq 0.369),(0.535-x) \geqq 0(x \leqq 0.535)$ という制限が
あり， $x$ が $0.369 \mathrm{~mol}$ ，すなわち $\mathrm{Ca}(\mathrm{OH})_{2}$ として 27.3 $\mathrm{g}$ の添加で $\mathrm{Al}_{2} \mathrm{O}_{3}$ はなくなり，エトリンガイトは 0.123 $\mathrm{mol}$ 生成し, 硫酸カルシウム二水和物は $0.166 \mathrm{~mol}$ (0.535-0.369) 未反応のまま残る.

以上の計算より，製紙スラッジ $200 \mathrm{~g}$ を $15 \%$ 硫酸溶 液 $200 \mathrm{ml}$ で処理し，これにスラグ $100 \mathrm{~g}$ を添加したも のに, 水酸化カルシウムを添加した場合には, 水酸化力 ルシウムの添加量が $7.0 \mathrm{~g}$ までは添加量の増加につれて 硫酸力ルシウム二水和物が増加し，7.0 34.3 g (7.0+ 27.3）の添加では硫酸カルシウム二水和物が減少し，工 トリンガイトの生成量が増加し, $34.3 \mathrm{~g}$ の添加で, 硫 酸カルシウム二水和物は $0.166 \mathrm{~mol}(0.535-0.369)$ と なり，エトリンガイトは $0.123 \mathrm{~mol}(0.369 / 3)$ 生成する. これ以上の添加では水酸化カルシウムはそのまま遊離の 状態で存在することになる.

\section{3 水酸化カルシウムの添加と X 線回折図の変化}

3.2 節で推定した反応を確かめるため, 製紙スラッジ, $15 \%$ 硫酸溶液，スラグの配合比， $200 \mathrm{~g} / 200 \mathrm{ml} / 100 \mathrm{~g}$ のものに水酸化カルシウムをそれぞれ $5 \mathrm{~g}, 10 \mathrm{~g}, 15 \mathrm{~g}$, $\cdots \cdots, 60 \mathrm{~g}$ 添加, 混練し, 24 時間後に固相の X 線回折 を行った．その結果の一部を図 5 に示した。

図 5 によると, 水酸化カルシウムの添加量が $20 \mathrm{~g}$ 以 下の配合物はいずれも製紙スラッジに起因するピーク

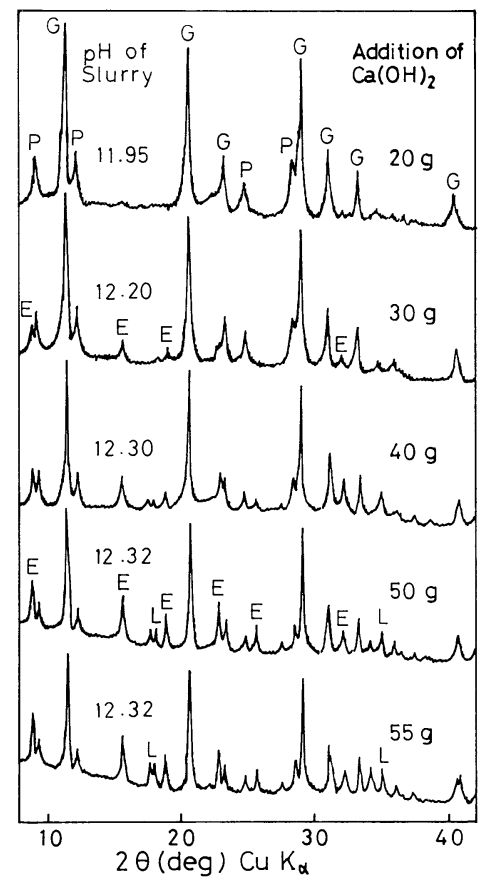

Fig. 5. X-ray diffraction patterns of hardened bodies containing various amount of $\mathrm{Ca}(\mathrm{OH})_{2}$ in paper sludge $200 \mathrm{~g}-15 \% \mathrm{H}_{2} \mathrm{SO}_{4} 200 \mathrm{ml}-\mathrm{slag} 100 \mathrm{~g}-\mathrm{Ca}(\mathrm{OH})_{2}, \mathrm{P}$ : Paper sludge, G: $\mathrm{CaSO}_{4} \cdot 2 \mathrm{H}_{2} \mathrm{O}, \mathrm{E}$ : Ettringite, L : $\mathrm{Ca}(\mathrm{OH})_{2}$. 
$\mathrm{P}$ と硫酸カルシウム二水和物のピーク $\mathrm{G}$ だけしか認め られず，硬化はしない，25 g 以上の添加量になると，P 及び $\mathrm{G}$ 以外にエトリンガイトのピーク $\mathrm{E}$ が出現し，い ずれも硬化し, 水酸化カルシウムの添加量が増加すると $\mathrm{G}$ のピークは小さくなり, エトリンガイトのピーク $\mathrm{E}$ が大きくなっている． 3.2 節の反応量の計算では水酸化 カルシウムの添加量が $7.0 \mathrm{~g}$ 以上でエトリンガイトが生 成し始めるはずであるが，エトリンガイト生成に対する 水酸化カルシウムの反応当量である $34.3 \mathrm{~g}$ に近くなら ないとエトリンガイトのピークは出現していない。その 理由は次のように考えられる。 $\mathrm{CaO}-\mathrm{Al}_{2} \mathrm{O}_{3}-\mathrm{CaSO}_{4}-\mathrm{H}_{2} \mathrm{O}$ 系におけるエトリンガイトの安定領域は $3 \mathrm{CaO}-\mathrm{Al}_{2} \mathrm{O}_{3}$ $3 \mathrm{CaSO}_{4}$ に相当する組成よりも $\mathrm{CaO}$ 及び $\mathrm{CaSO}_{4}$ の過 剩な領域に片寄っている51. そのため, 水酸化カルシウ ムの添加量が $20 \mathrm{~g}$ 以下ではスリラーの $\mathrm{pH}$ は 12.0 以下 で, 液相中の $\mathrm{CaO}$ 濃度は低く $(\mathrm{pH}$ 值よりの計算では $0.28 \mathrm{~g} / \mathrm{l}$, 飽和石灰水では $1.13 \mathrm{~g} / \mathrm{l}, \mathrm{pH}$ は 12.6$)$, 液相 の $\mathrm{CaO} / \mathrm{Al}_{2} \mathrm{O}_{3}$ 比が小さくなり，エトリンガイトの安定 領域からはずれ，エトリンガイトが生成しにくかっだ ものと考えられる. また, $30 \mathrm{~g}$ 以上では添加量が増加 するとピーク $\mathrm{E}$ は大きくなり，凝結も早くなるが，工 トリンガイトの生成量は $\mathrm{Al}_{2} \mathrm{O}_{3}$ 量 $(0.123 \mathrm{~mol})$ で支配 されるので, 水酸化カルシウムによる凝結促進には限界 があるものと考えられる.なお，反応当量 $(34.3 \mathrm{~g})$ 以 上に添加した水酸化カルシウムはそのまま遊離の状態で 存在することになる. 図 5 の X 線回折図では水酸化力 ルシウム $40 \mathrm{~g}$ 添加以上で $\mathrm{Ca}(\mathrm{OH})_{2}$ に帰属するピーク $\mathrm{L}$ が現れている. しかし，このピークは添加量が増加して もあまり大きくなっていない，また，この硬化体を水中 養生すると L は更に小さくなることにより，反応当量 以上に添加した水酸化カルシウムはスラグと硫酸との反 応で生じた反応しゃすい $\mathrm{SiO}_{2}$ 成分と $\mathrm{CaO}-\mathrm{SiO}_{2}-\mathrm{H}_{2} \mathrm{O}$ 系化合物を生成していることも考えられる.

\section{4 凝結，硬化に及ぼすアルミン酸ナトリウムの影 響}

この系の凝結促進剤としてポルトランドセメント，塩 化カルシウム, 硫酸カルシウム二水和物等多くの物質を 検討したが,これらの中でエトリンガイトの生成に関係 が深いアルミナセメント, 硫酸アルミニウム, アルミン 酸ナトリウムが促進効果が大きかった。この系の凝結, 硬化に対する影響としては硫酸アルミニウムは少し異な るが，アルミナセメントとアルミン酸ナトリウムはほと んど同じであるので, 主に組成の簡単なアルミン酸ナト リウム添加の影響について述べる。

製紙スラッジ，15％硫酸，スラグ，水酸化カルシウ ムの配合比, $200 \mathrm{~g} / 200 \mathrm{ml} / 100 \mathrm{~g} / 50 \mathrm{~g}$ の配合物にアル ミン酸ナトリウム（試薬 1 級 $\mathrm{NaAlO}_{2}$ ) を添加したとき の凝結曲線を図 6 に示した。ただし，アルミン酸ナトリ

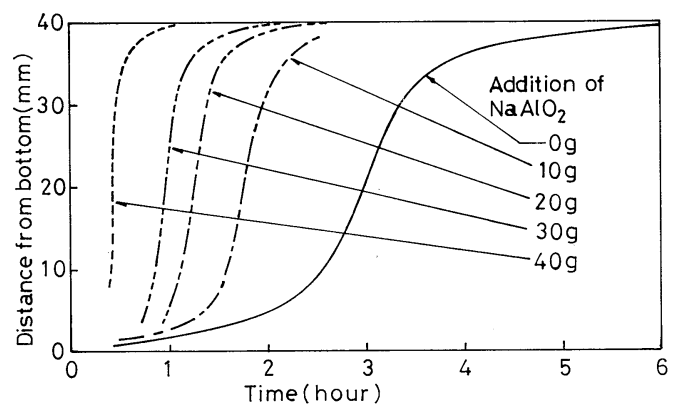

Fig. 6. Effect of $\mathrm{NaAlO}_{2}$ addition on setting curves in paper sludge $200 \mathrm{~g}-15 \% \mathrm{H}_{2} \mathrm{SO}_{4} 200 \mathrm{ml}$-slag $100 \mathrm{~g}-\mathrm{Ca}$ $(\mathrm{OH})_{2} 50 \mathrm{~g}$.

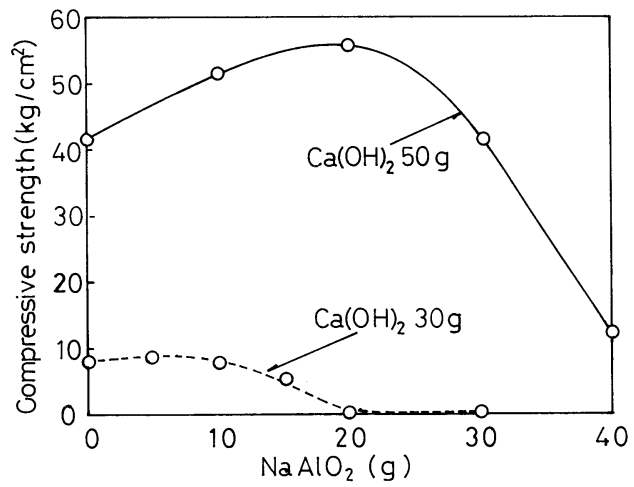

Fig. 7. Effect of $\mathrm{NaAlO}_{2}$ amount on strength of hardened bodies in paper sludge $200 \mathrm{~g}-15 \% \mathrm{H}_{2} \mathrm{SO}_{4} 200 \mathrm{ml}$ slag $100 \mathrm{~g}-\mathrm{Ca}(\mathrm{OH})_{2} 30 \mathrm{~g}$ or $50 \mathrm{~g}$.

ウムは純水 $50 \mathrm{ml}$ に溶解または懸濁した状態で添加し た。

アルミン酸ナトリウムの添加量が増加すると凝結は早 くなり, 凝結曲線は左側に移動し, $40 \mathrm{~g}$ 添加ではアル ミン酸ナトリウム添加後数分で疑結が始まり，1 時間く らいで終結となる(凝結針の侵入度が $35 \mathrm{~mm}$ 及び $5 \mathrm{~mm}$ になる時間を便宜上始発時間及び終結時間と呼ぶ）．更 に添加量を増加すると凝結は更に早くなり, 瞬結となり, 混練が不可能となる.

このように, アルミン酸ナトリウムの添加では, 添加 量の増加に従って凝結は早くなるが, 強度は必ずしも大 きくはならない，圧縮強さに及ぼすアルミン酸ナトリウ ムの影響を図 7 に示した.

アルミン酸ナトリウムの添加量が $10 \mathrm{~g}, 20 \mathrm{~g}$ と増加 すると強度も増大するが, 添加量が $30 \mathrm{~g}$ 以上になると 凝結が早くなっているにもかかわらず, 逆に強度は急激 に低下している.

アルミン酸ナトリウムの添加量と強度との関係は配合 物中の水酸化カルシウムの含有量によって非常に異な る. 図 7 に水酸化カルシウムの含有量の少ない $30 \mathrm{~g}$ (配 合比, $200 \mathrm{~g} / 200 \mathrm{ml} / 100 \mathrm{~g} / 30 \mathrm{~g}$ ）の配合物にアルミン酸 
ナトリウムを添加したときの圧縮強さも示したが，この 配合物は $50 \mathrm{~g}$ 含有物と異なり,アルミン酸ナトリウム の添加による強度の増大はほとんどなく, $20 \mathrm{~g}$ 以上の 添加では逆に硬化しなくなる.

\section{5 凝結，硬化に及ぼすアルミン酸ナトリウムの作 用機構}

凝結，硬化に及ぼすアルミン酸ナトリウムの作用を明 らかにするため, アルミン酸ナトリウムの添加量を変え たものの X 線回折を行った。 まず水酸化カルシウムの 含有量 $50 \mathrm{~g}$ の配合物にアルミン酸ナトリウムを添加し たときの混練後 24 時間の固相の X 線回折図を図 8 に示 した.

図 8 によると,アルミン酸ナトリウムの添加量が 10 $\mathrm{g}, 20 \mathrm{~g}$ と増加すると硫酸カルシウム水和物のピーク $\mathrm{G}$ は急激に減少し，エトリンガイトのピーク $\mathrm{E}$ は大きく なる. 強度の最も大きい $20 \mathrm{~g}$ の添加で, エトリンガイ トのピーク E は最大となるが，それ以上の添加ではほ とんよ゙変化がない。したがって，アルミン酸ナトリウム を添加すると，この配合物中に存在した硫酸カルシウム 二水和物及び遊離の水酸化カルシウムと添加したアルミ ン酸ナトリウムが反応し, エトリンガイトを生成し, 強度を增加したものと考えられる. しかし，20 g の添 加で，硫酸カルシウム二水和物はほとんど反応に消費さ れてしまう。そこで，これ以上添加しても新しいエトリ ンガイトの生成はなく, 添加したアルミン酸ナトリウム は $\mathrm{Ca}(\mathrm{OH})_{2}$ と反応し，アルミン酸カルシウム水和物を 生成し，凝結は促進するが，エトリンガイトが減少する ので, 強度は低下したものと考えられる.

次に，水酸化カルシウムの含有量 $30 \mathrm{~g}$ の配合物にア

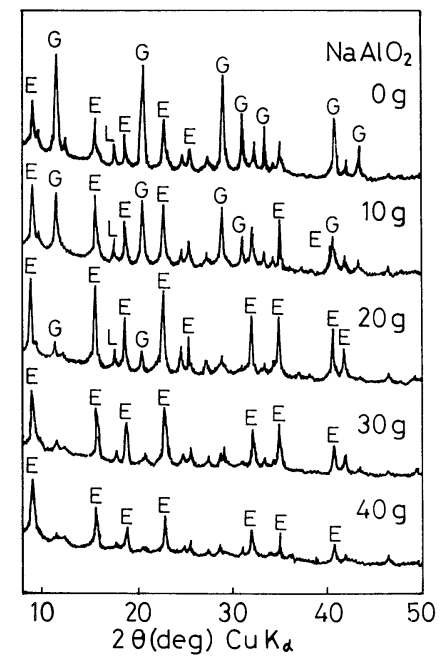

Fig. 8. X-ray diffraction patterns of hardened bodies containing various amount of $\mathrm{NaAlO}_{2}$ in paper sludge $200 \mathrm{~g}-15 \% \mathrm{H}_{2} \mathrm{SO}_{4} 200 \mathrm{ml}$-slag $100 \mathrm{~g}-\mathrm{Ca}(\mathrm{OH})_{2} 50 \mathrm{~g}$. P : Paper sludge, $\mathrm{G}: \mathrm{CaSO}_{4} \cdot 2 \mathrm{H}_{2} \mathrm{O}, \mathrm{L}: \mathrm{Ca}(\mathrm{OH})_{2}$.

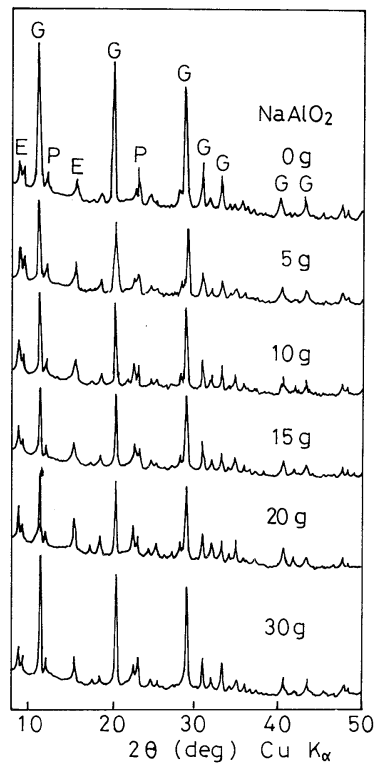

Fig. 9. X-ray diffraction patterns of hardened bodies containing various amount of $\mathrm{NaAlO}_{2}$ in paper sludge $200 \mathrm{~g}-15 \% \mathrm{H}_{2} \mathrm{SO}_{4} 200 \mathrm{ml}$-slag $100 \mathrm{~g}-\mathrm{Ca}(\mathrm{OH})_{2} 30 \mathrm{~g}$. P : Paper sludge, G: $\mathrm{CaSO}_{4} \cdot 2 \mathrm{H}_{2} \mathrm{O}$, E : Ettringite.

ルミン酸ナトリウムを添加したときの X 線回折の結果 在図 9 に示した。

水酸化カルシウムの含有量 $30 \mathrm{~g}$ の配合物は水酸化力 ルシウムのピークは認められない。これにアルミン酸ナ トリウムを添加した場合には，5g 添加でわずかに硫酸 カルシウム二水和物のピーク $G$ が小さくなるが，これ 以上添加量を増加しても，硫酸カルシウム二水和物の ピーク Gもエトリンガイトのピークもほとんど変化が ない。したがって, 水酸化カルシウムの含有量が少ない $30 \mathrm{~g}$ の配合物では遊離の水酸化カルシウムがほとんど 存在しないので，アルミン酸ナトリウムを添加しても工 トリンガイトの生成がなく, 強度低下したものと考えら れる.

以上，製紙スラッジ，15％硫酸溶液，スラグ，水酸 化カルシウムの配合比，200 g/200 ml/100 g/50 g の配 合物または $200 \mathrm{~g} / 200 \mathrm{ml} / 100 \mathrm{~g} / 30 \mathrm{~g}$ の配合物の凝結, 硬化に及ぼすアルミン酸ナトリウムの作用機構を整理す ると次のようになる。

製紙スラッジと硫酸が反応しないと仮定すれば，水酸 化カルシウム添加までの実験は 3.2 節の計算がそのまま 当てはまり，製紙スラッジ $200 \mathrm{~g}$ を $15 \%$ 硫酸溶液 200 $\mathrm{ml}$ で処理し，これにスラグ $100 \mathrm{~g}$ を添加したものに, 水酸化カルシウムを $34.3 \mathrm{~g}$ 添加すれば, エトリンガイ トが $0.123 \mathrm{~mol}$ 生成し, 硫酸カルシウム二水和物が $0.186 \mathrm{~mol}$ 末反応のまま残る (表 3 参照).

水酸化力ルシウムを $34.3 \mathrm{~g}$ 以上添加すれば， $34.3 \mathrm{~g}$ 以上の水酸化カルシウムは未反応のまま遊離の状態で存 
在する.遊離の水酸化カルシウムが $0.186 \mathrm{~mol}(13.8 \mathrm{~g})$ 以上存在すれば，更に $\mathrm{Al}_{2} \mathrm{O}_{3}$ 成分を $0.062 \mathrm{~mol} \mathrm{(0.186/}$ $3 \mathrm{~mol})$ 添加することにより，未反応のまま残っていた 硫酸カルシウム二水和物 $0.186 \mathrm{~mol}$ を利用して, (3) 式により，エトリンガイトを更に $0.062 \mathrm{~mol}$ 生成させる ことができる.

配合比, $200 \mathrm{~g} / 200 \mathrm{ml} / 100 \mathrm{~g} / 50 \mathrm{~g}$ の配合物では硫酸 カルシウム二水和物が $0.186 \mathrm{~mol}$ と水酸化カルシウム $15.7 \mathrm{~g}(50-34.3,0.212 \mathrm{~mol})$ が遊離の状態で存在する. これにアルミン酸ナトリウムを添加すれば，この硫酸力 ルシウム二水和物を利用して，エトリンガイトを生成す るので，添加量の増加にしたがって硫酸カルシウム二水 和物が減少し，エトリンガイトが増加し，添加量が $\mathrm{Al}_{2} \mathrm{O}_{3}$ として $0.062 \mathrm{~mol}$ (試薬アルミン酸ナトリウムで は $\mathrm{Al}_{2} \mathrm{O}_{3}$ の含有量が $35 \%$ であるので, $18.1 \mathrm{~g}(=0.062$ $\times 101.96 / 0.35))$ で, 硫酸カルシウム二水和物は 0 とな り，エトリンガイトの生成量が最大となるはずである. 図 8 の固相の X 線回折の結果はこの計算值とほぼ一致 し，アルミン酸ナトリウムの添加量が増加すると硫酸力 ルシウム二水和物のピーク $\mathrm{G}$ が減少し, $20 \mathrm{~g}$ でほとん ど 0 となり，逆にエトリンガイトのピーク $\mathrm{E}$ が大きく なっている．また圧縮強さも $20 \mathrm{~g}$ 添加で最高の強度が 得られている.

水酸化カルシウムの含有量の少ない配合比, 200 $\mathrm{g} / 200 \mathrm{ml} / 100 \mathrm{~g} / 30 \mathrm{~g}$ の配合物では，水酸化カルシウム の含有量はエトリンガイトの生成に対する反応当量 $34.3 \mathrm{~g}$ 上り少ない. したがって, 硫酸カルシウム二水 和物があっても水酸化カルシウムがないので, アルミン 酸ナトリウムを添加しても，新しいエトリンガイトの生 成がなく，強度はむしろ低下するものと考えられる．図 9 の X 線回折の変化及び強度試験の結果はこの計算値 とほぼ一致している。なお，エトリンガイトの生成がな くても，アルミン酸塩（アルミナセメントを含む）の添 加により凝結が早くなることより，アルミン酸イオンと カルシウムイオンよりアルミ酸カルシウム水和物を生成 し，凝結が促進されたものと考えられる.

\section{4. まとめ}

以上の結果より，製紙スラッジ-硫酸-スラグ-水酸化 カルシウム系の凝結, 硬化反応及びその反応に及ぼすア ルミン酸ナトリウムの作用は次のようになると考えられ る.

（1）製紙スラッジに硫酸を加え，スラッジの硫酸処
理を行ったものにスラグを添加すると，スラグ中の $\mathrm{CaO}$ 成分と $\mathrm{MgO}$ 成分は塩基性成分としてスラッジ中 の硫酸と定量的に反応し, 硫酸カルシウム二水和物と硫 酸マグネシウムを生成する．硫酸と反応したスラグ中の $\mathrm{Al}_{2} \mathrm{O}_{3}$ 成分及び $\mathrm{SiO}_{2}$ 成分は反応しやすい状態となる。

（2）これに水酸化カルシウムを添加すると，まず硫 酸マグネシウムと反応し, 硫酸カルシウム二水和物と水 酸化マグネシウムを生成した後，スラグ中の反応しやす い $\mathrm{Al}_{2} \mathrm{O}_{3}$ 成分を使用して, $\mathrm{Ca}(\mathrm{OH})_{2}-\mathrm{CaSO}_{4}-\mathrm{Al}_{2} \mathrm{O}_{3}-\mathrm{H}_{2} \mathrm{O}$ 系よりエトリンガイト $\left(3 \mathrm{CaO} \cdot \mathrm{Al}_{2} \mathrm{O}_{3} \cdot 3 \mathrm{CaSO}_{4} \cdot 31 \mathrm{H}_{2} \mathrm{O}\right)$ が生成し，凝結，硬化する。

（3）エトリンガイトの生成反応は水酸化カルシウム の添加量によって非常に異なり，添加量がエトリンガイ 卜生成の反応当量 $\left(\mathrm{CaO} / \mathrm{Al}_{2} \mathrm{O}_{3}=3.0\right)$ 以下ではエトリ ンガイトが生成しにくく，硬化不良となり，これ以上の 添加量では添加量の増加につれてエトリンガイトの生成 量も増加し，凝結が早くなり，強度も大きくなる，ただ し, 最大生成量は $\mathrm{Al}_{2} \mathrm{O}_{3}$ 成分量によっても支配されるの で，水酸化カルシウム添加による凝結促進には限界があ る.

（4）この系の凝結促進にはアルミン酸塩の添加が非 常に有効であり，アルミン酸ナトリウムの添加により， 終結時間が 6 時間のものを 1 時間以内まで短縮できた.

（5）系中に遊離の水酸化カルシウム及び硫酸カルシ ウム二水和物がエトリンガイトの反応当量 $\left(\mathrm{CaO} / \mathrm{CaSO}_{4} / \mathrm{Al}_{2} \mathrm{O}_{3}=3 / 3 / 1\right)$ 以上存在し, アルミン 酸塩 $\left(\mathrm{Al}_{2} \mathrm{O}_{3}\right)$ の添加により新しくエトリンガイトが生 成すれば, 凝結が早くなり, 強度も増加する.

（6）系中に遊離の水酸化カルシウム又は硫酸カルシ ウム二水和物が存在せず，アルミン酸塩を添加しても工 トリンガイトを生成しない場合には, 添加したアルミン 酸イオンと系中のカルシウムイオンと反応し，アルミン 酸カルシウム水和物を生成し，凝結は促進されるが，工 トリンガイトはむしろ減少するので，強度は減少する．

\section{文献}

1）下野健一, 桑原啓至, 牧田輝夫, 日吉公男, 山本登久男, 紙パルプの技術，30，33-46 (1979).

2）青木繁樹, 荒井康夫, 石膏と石灰, 175，17-23 (1981).

3）青木繁樹, 荒井康夫, 石膏と石灰, 183，16-24 (1983).

4）青木繁樹, 木兽正光, 荒井康夫, 石膏と石灰, 191，2432 (1984).

5) F. M. Lea, "The Chemistry of Cement and Concrete, Edward Arnold (Publishers) Ltd (1970) p. 226-28.

6) F.M. Lea, "The Chemistry of Cement and Concrete", Edward Arnold (Publishers) Ltd (1970) p. 223-24. 